\title{
NEGRO CHILDREN IN THE PUBLIC SCHOOLS OF PHILADELPHIA ${ }^{1}$
}

\author{
By Howard W. Odum, \\ University of Georgia, Athens, Ga.
}

That the problem of educating Negro children is not limited in its application to any community, or to the North or South, is now a well recognized fact. That it is of special importance in the study of American education; is closely related to many problems of public policy; and bears directly upon the theory and practice of efficiency in national life, as well as upon race improvement, is not always so well recognized.

At the invitation and with the coöperation of Dr. Martin G. Brumbaugh, superintendent of the city public schools, this study was undertaken by the Philadelphia Bureau of Municipal Research with a view to assisting in the solution of a difficult problem of school administration and efficiency. The inquiry was pursued on the assumption that little could be done unless the subject was approached strictly from the objective viewpoint and prosecuted with as much thoroughness as possible. At the same time it is a practical study and the time and facilities for making exhaustive experiments and anthropometric measurement were very limited. It is urged, therefore, that all facts and conclusions herein presented shall be interpreted accordingly, and that all statements concerning Negro children be interpreted as applying to Negro children as they are today, the product of inheritance and environment.

This paper is, further, a summary of a large body of information. In order to employ summaries with exactness it is necessary to interpret totals, averages, and central tendencies in their relation to the frequencies upon which they are baser. It is possible, for instance, to have two groups of a thousand children each, conforming alike to average measurements, and at the same time differing so radically in their conformation to normal distribution as to be almost wholly

'Summary from a special study of Negro children in the public schools of Philadelphia made for the Philadelphia Bureau of Municipal Research. 
unlike. Such a series of variations not infrequently occurs in exactly those traits, a knowledge of which is essential to an understanding of the groups. In attempting to form conclusions from a general summary, therefore, it is most important to keep these facts in mind. And while it is possible to summarize to a large extent the principal facts brought out in this study of Negro children in the schools, it is also easy to neglect fundamental minor facts that may be shown only in the detailed units of scope and method. With these qualifications the following summary ought to be of value.

The scope of this inquiry included all the elementary schools of the Philadelphia public school system as organized during the months from September, 1910, to January, 1911, the information concerning enrollment and attendance being obtained at that time, and the experiments being made during that period and subsequently. The total number of pupils enrolled in the elementary schools was 154,125 , of which 8,192 or 5.3 per cent were Negro children. This enrollment was made from a total number of enumerable children of 241,623 , of whom 9,758 were Negroes; and they were enrolled in the 238 elementary schools with their several annexes. The larger study thus includes this total number and the larger comparisons are made between total children and Negro children. The larger group is again variously divided. There were two principal groups of Negro children, those who attend mixed schools for whites and Negroes, and those who attend schools in which only Negro children are enrolled. Again, smaller groups are made the basis of special experiments and minute study, the effort being to approximate in all cases, so far as possible, similar conditions for both white and Negro children, with experiments made uniformly by the same person.

Of the total Negro pupils enrolled in the public elementary schools approximately one-fourth (23.7 per cent) were enrolled in nine separate Negro schools, the remaining three-fourths (76.3 per cent) being enrolled largely in 15 per cent of the total schools of the city. Thirtyone per cent of the schools of the city have no Negro pupils enrolled, 23 per cent have less than 1 per cent, and 20 per cent have between 1 and 5 per cent. The problem of the Negro child is thus seen to rest chiefly upon a relatively small proportion of the schools, and its intensity varies widely in the various schools. Again, the problem varies in the several school districts, being largest in the 4th district where 12 per cent of the pupils enrolled are Negroes, comprising 
20 per cent of the total Negro school population, although the district has less than one-tenth of the whole school population. And similarly for other districts. Negro children constitute 5.3 per cent of all children enrolled in the city, but constitute only 4 per cent of all children enumerated in the city, thus showing a higher rate of enrollment than white children. The Negroes have a larger proportion of females in schools than the whites, the former showing only 50.4 per cent girls while the Negroes show 52.8 per cent. The increase of Negro children in the proportion of total population for the last five years was 0.5 per cent and the distribution of these children in the different wards shows a larger scope of the race school problem. The shifting from ward to ward in the school population was a little more than twice as large for the Negroes as for the whites. The proportion of the enumerated whites and Negroes enrolled is about the same but more Negro children remain in schools from fourteen to sixteen years of age. The Negro children show 72.4 per cent of all Negro children from fourteen to sixteen years of age enrolled, and the whites only 59.7 per cent. Ninety-five per cent of Negro children are enrolled in public schools and only 74 per cent of white children. The Negro children constitute, therefore, preëminently a public problem.

Further study of distribution shows that a much larger proportion of Negro pupils are enrolled in the primary grades than are white pupils. Of the Negro pupils enrolled 77.8 per cent, and of the white pupils 67.8 per cent are enrolled in primary grades. Again, 4 per cent of the white children reach the eighth grade as opposed to 2.3 per cent of the Negro children. Of the white girls enrolled 33.1 per cent, and of the white boys 31 per cent are enrolled in grammar grades. Compare this with 25.9 per cent of Negro girls and 17.4 per cent of Negro boys enrolled in grammar grades. Negro girls thus remain in school considerably longer than Negro boys. The separate Negro schools enroll pupils chiefly in the primary grades, only 9 per cent being enrolled in the grammar grades. The Negro pupils in the higher grades are thus distributed throughout the mixed schools. While a smaller number of Negro pupils reach the higher grades than the whites, a larger number remain in school to a later age. Only 2.6 per cent of the total pupils of the city remain in school above fourteen years of age, the normal age for the completion of the eighth grade, while 8.6 per cent of the Negroes enrolled are over fourteen years of age. Thus, a large part of the white children finish under age and a 
large part of Negro children remain in school beyond the normal age. The Negro girls in school are older than the Negro boys. Among both white and Negro pupils the largest number is enrolled at the age of ten years. But the proportion of Negro children at the ages of five, six and seven is much smaller; and at the ages of fourteen, fifteen, sixteen and seventeen much larger than among the whites. The ages of Negro pupils in separate Negro schools approximate those of the white children. The total Negro children extend in appreciable numbers from six to eighteen years and the whites from six to sixteen. The average age for all children in the schools is 9.3 years and for all Negro children is 10.6 years. That is, the Negroes average a year and a third older than the white children. The differences between the average ages of white and Negro pupils is larger than this in the majority of grades. The following table shows the average age for each grade and the difference between white and Negro pupils.

Average Age of Pupils by Grades

\begin{tabular}{|c|c|c|c|}
\hline Grade & White children & Negro chlldren & Difference \\
\hline First. . . . . . $\ldots \ldots \ldots \ldots \ldots$ & 6.7 & 7.6 & 0.9 \\
\hline Second $\ldots \ldots \ldots \ldots \ldots \ldots$ & 8.2 & 9.4 & 1.2 \\
\hline Third..... & 9.5 & 10.9 & 1.4 \\
\hline Fourth......... & 10.7 & 12.1 & 1.4 \\
\hline Fifth.......... & 11.6 & 13.1 & 1.5 \\
\hline Sixth.............. & 12.4 & 13.9 & 1.5 \\
\hline Seventh... & 13.2 & 14.6 & 1.4 \\
\hline Eighth . . . . . . . . & 13.9 & 15.5 & 1.6 \\
\hline
\end{tabular}

The average of Negro pupils in each grade is again compared with the normal age.

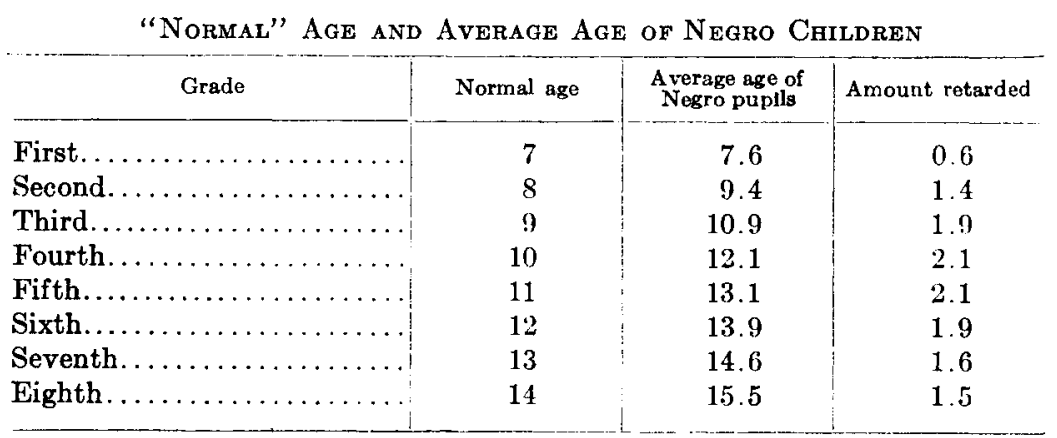


Whereas the Negro pupils in the eight grade are a year and half over age, the white pupils finish a little under the normal age. Again, in the third, fourth, fifth and sixth grades the Negro pupils average two years older than the normal age, and except in the first grade they average a year and a half or more above the normal age. The average for the Negro children in the sixth grade is exactly the same as that for the white children in the eighth grade.

The Negro children also show a larger average deviation than the white. The following table gives the further comparison between white and Negro children.

\begin{tabular}{|c|c|c|c|c|c|c|}
\hline \multirow{2}{*}{ Grade } & \multicolumn{3}{|c|}{ WHITE PUPILS } & \multicolumn{3}{|c|}{ NEGRO PUPILS } \\
\hline & $\begin{array}{l}\text { Number } \\
\text { of pupils }\end{array}$ & $\begin{array}{c}\text { Average } \\
\text { age }\end{array}$ & $\begin{array}{c}\text { Average } \\
\text { deviation }\end{array}$ & $\begin{array}{l}\text { Number } \\
\text { of pupils }\end{array}$ & $\begin{array}{c}\text { Average } \\
\text { age }\end{array}$ & $\begin{array}{c}\text { Average } \\
\text { deviation }\end{array}$ \\
\hline First. . & 29,220 & 6.7 & 0.8 & 1,855 & 7.6 & 1.1 \\
\hline Second. & 25,378 & 8.2 & 0.9 & 1,648 & 9.4 & 1.2 \\
\hline Third. . & 24,153 & 9.5 & 1.0 & 1,475 & 10.9 & 1.3 \\
\hline Fourth. & 21,685 & 10.7 & 1.1 & 1,095 & 12.1 & 1.2 \\
\hline Fifth... & 18,438 & 11.6 & 1.0 & 749 & 13.1 & 1.1 \\
\hline Sixth...... & 13,516 & 12.4 & 0.9 & 500 & 13.9 & 1.0 \\
\hline Seventh.... & 9,196 & 13.2 & 0.9 & 308 & 14.6 & 1.0 \\
\hline Eighth. & 6,869 & 13.9 & 0.9 & 186 & 15.5 & 1.0 \\
\hline
\end{tabular}

From the study of these ages of white and Negro children in the grades it will be seen that there is a high percentage of retardation among Negro children. A summary of the detailed figures of age and grade classifications shows the following facts. With both white and Negro children the highest percentage of pupils above normal age is in the fifth grade. With both white and Negro children the largest percentage below normal age is in the first grade. With white children the highest percentage of normal age children is in the seventh grade while with the Negro children it is in the first grade.

The total Negro pupils show 71.9 per cent retardation, and the white children 38.9 per cent according to the accepted standard which allows one year normal age for each grade. According to a more accurate standard, allowing three years range for each grade, the Negroes show 48.6 per cent retardation and the whites 18.6 per cent. Again, the Negro pupils have 23.2 per cent retarded one year, 21.9 per cent retarded two years, 14.6 per cent retarded three years, 7.9 per cent retarded four years, 3.6 per cent retarded five years, 1.4 
per cent retarded six years and 0.2 per cent retarded seven years. The white pupils show 20.2 per cent retarded one year, 11.2 per cent retarded two years, 4.8 per cent retarded three years, 1.7 per cent four years, and 0.5 per cent five years. With both white and Negro children the boys show slightly more retardation than the girls. Negro pupils in separate Negro schools have only 66.7 per cent retardation as opposed to 73.7 per cent among Negro children in mixed schools. The total pupils of all schools show 30.6 per cent below normal age and 30.5 per cent normal, while Negro children show only 8.2 per cent below normal age and 19.9 per cent normal. The 72 per cent retarded Negro pupils of Philadelphia may be compared with the Negro pupils of Memphis, 75.8 per cent, and with 3,670 Philadelphia pupils with defective vision having 75 per cent retardation.

In high schools Negro boys are retarded 60 per cent and Negro girls 74.6 per cent; white boys are retarded 27.4 per cent and white girls 24.1 per cent. The number of Negro pupils in the high school, however, is small. Among the whites there are in the high school about sixty pupils to every 1,000 enrolled in elementary schools, while for the Negroes there are only twenty-one or about 2 per cent. Again, for each 1,000 Negro boys there are ten in the high school and for Negro girls thirty, while for white boys there are sixty-one, and for white girls fifty-seven to each 1,000 in the elementary schools.

Ayres shows that attendance is an important factor in retardation. Having shown the high percentage of retardation among Negro children, it is necessary to inquire into their attendance and promotion. The average attendance for five years among the total pupils of the city was 87.7 per cent and for Negro pupils in the Negro schools 78.8 per cent, a difference amounting to 10 per cent of the total average attendance. The irregularity of the Negro pupils' attendance is made up of lateness, days missed, and late entrance or early leaving school. The white children show only 0.7 per cent of lateness and the Negro pupils show 3.1 per cent or more than four times that of the white children. In no case do Negro schools have as high record of attendance as the average whites. In no case do the white schools show as low percentage of attendance as the average Negro schools. Likewise, in no case do the Negro schools approximate so low a percentage of lateness as the average whites, and in no case do the white schools show so high a percentage of lateness as the average Negro schools. Among 
the total pupils of the city 3.3 per cent were reported as remaining in their grades more than twenty months and 0.8 per cent more than thirty months. Among Negro pupils in Negro schools 9.5 per cent remained in their grades more than twenty months and 1.2 per cent more than thirty months. Among Negro pupils in mixed schools 9.2 per cent remained in grades more than twenty months, and 1.1 per cent more than thirty months. That is, three times as many Negro pupils as whites remain in grades more than twenty months, and six times as many more than thirty months. Of Negro pupils in mixed schools 19 per cent remained in grades fifteen months or more and some 25 per cent repeated grades to some extent.

Ayres points out the fact that bad effects of low percentages of promotion increase with astonishing rapidity as each successive decrease of the percentage promoted is made. Thus a difference of 10 per cent in the percentage of promotions is much more than twice as much as 5 per cent. He shows that a difference of seven points in the percentage of promotions, for instance, may cause a difference in the number of pupils with clear records, in each 1,000 pupils, of 220. That is, with a special average of 90 per cent promotions in a case where no pupils die or drop out of school, 480 pupils out of every 1,000 reach the eighth grade without failing, while with an average of 83 per cent only 260 reach the eighth grade without failing. According to this standard of reckoning among the total pupils of the Philadelphia schools 240 pupils of every 1,000 will reach the eighth grade without failure, and among the Negro pupils only about 50 would reach the eighth grade without failure. That is, the percentage of promotions among the total pupils of the schools is 81.8 and among Negro pupils in Negro schools 70.6 and among Negroes in mixed schools 71 per cent. There is, thus, a large difference between the reports of white and Negro children, but little difference between the two groups of Negroes. The largest difference between promotions by grades between white and Negro children are in the first, fifth and seventh grades. Among Negro pupils there is little variation in the different ages of percentages of promotions, and little variation between boys and girls.

The average markings by teachers reported for Negro children were $70 ; 69$ for boys and 71 for girls. However, the range was wide, there being some 5 per cent with grades of ninety, and 25 per cent with grades of eighty. Of the pupils having grades of ninety, the 
earlier grades have a slightly larger proportion than the later grades and the girls excel the boys by a small margin. Again, 4.9 per cent of Negro pupils in mixed schools were reported at the head of their class, 20.9 per cent were in the upper quarter, 39.6 per cent were in the middle half, and 34.3 per cent were in the lower quarter. In the numerical rating pupils below the age of thirteen furnish the largest proportion of grades above seventy and likewise higher averages, and the older pupils show a consequent smaller proportion of higher grades, and lower averages. The largest proportion of nineties is found at eight and nine years and the largest proportion of eighties at eleven years. The highest average grade, seventy-two, is found at eleven years, and the averages vary from seventy at seven years of age to sixty-two at seventeen. The girls show a slightly better record in both averages and the number having grades of eighty and ninety.

According to the teachers, Negro children find most difficulty in arithmetic and studies that require compound concentration and prolonged application. Seventy per cent of Negro pupils reported show their poorest work in arithmetic, as compared with 52 per cent of white children. Language, after arithmetic, furnishes the greatest difficulty. Reading and spelling offer comparatively the least difficulties to Negro pupils. Among Negro pupils in mixed schools 32.7 per cent are reported unsatisfactory in deportment and among white pupils 22.9 per cent. Of the Negro children having a grade of ninety or being at the head of their classes, only 14.3 per cent were reported unsatisfactory while more than 40 per cent had excellent deportment. Likewise the deportment of all Negro children having better marks and standing in the upper quarter of class work was consistently better. Again, Negro children coming from better and average homes have better deportment than those coming from the poorest homes. Likewise the poorest class of Negro homes furnish only a small proportion of pupils having the highest grades. Negro girls have slightly better deportment than Negro boys. There is thus a decided positive correlation between deportment and good work. The offenses charged to Negro pupils are many and the correction and the effective training of colored pupils offer a large field for constructive work.

Before forming conclusions from the above facts it is necessary to inquire into their causes and meaning. It should be remembered, too, that there are many exceptions to the totals and averages there reported. That is, in every phase of school life the Negro children 
show a tendency to reach or excel the median of the white children, and the range from lowest to highest among Negro children tends to become wider than among the whites. Before inquiring into the specific race differences, as reflected in Negro children and white children, it will be necessary to analyze as many as possible of the environmental influences that tend to change the records made in school. The correlation of the home and social environment, together with present racial influences, with school records will indicate the source of many difficulties which the Negro children have to face. When these influences have been estimated it will be possible to seek remedies for defects which exist under the present conditions and to estimate the extent to which permanent changes are necessary and upon what basis they may be advocated.

The grade distribution, retardation and promotion of pupils are so inter-related that their causes may be considered together. The prevailing practice among children in all public schools tends to cause them to drop out of the elementary schools at fourteen years of age. There are two main causes for this. Fourteen years is the normal age for the completion of the eighth grade, whence children either drop out of school altogether or enter the high school. But if they have not finished at that age the compulsory education requirements permit them to drop out of school at that time. Among the total children of the public schools only 2.6 per cent remain to a later age than fourteen years. Among Negro children 8.6 per cent are above fourteen years of age. Now it has been seen that the average age for total children in the eighth grade was exactly the same as for Negro children in the sixth grade. This age is 13.9 years. The Negro pupil must either drop out at the sixth grade or remain in school to an average age of 15.6 years. This partly explains the smaller number who reach the eighth grade among Negro children and likewise the reasons for remaining in school longer than the whites. That is, if the Negro children dropped out at the age of fourteen as do the whites, there would be no seventh and eighth grade pupils. Now the Negro pupils do tend to drop out, but not all, hence the few who remain to the eighth grade. Again, there is often less incentive offered Negro children to drop out than white children, owing to the limited field of work open to Negro boys and girls at that age. Of course, the question of the aptitude of Negro pupils to do the work of higher grades is an important factor as will be seen, but all should not be ascribed to 
this. It is a common fallacy to assume that because Negro pupils are not enrolled in the higher grades, they therefore cannot do the work given in those grades. In addition to the causes which make them retarded and thus cause the elimination by age, there are other factors than those suggested. The separate schools for Negro children offer chiefly work in the primary grades, while the grammar grade Negro pupils attend the mixed schools entirely. It has been shown in some specific instances that Negro pupils attending crowded classes in the upper grades and competing with white children, with what they feel to be unequal odds, owing to their higher age, and discrimination on the part of teachers and pupils, have preferred to leave school rather than attend under these circumstances. And unless there are home influences or age requirements to keep them in school the elimination is easy. This element enters to some extent in all mixed schools and it is not possible to analyze influences to fix the exact amount.

But assuming, first, that the age elimination is largest, it is necessary to inquire into the causes of retardation. This in turn will have a direct relation to the promotion of Negro pupils and hence will throw light on the question of their aptitude to do the work of higher grades. It was shown that the Negro pupils approximate twice as much retardation as the white pupils according to the accepted standard of normal age and that according to a more refined standard they approximate three times as much. Further it was shown that in the majority of grades the Negro pupils are consistently two years behind the white children. Is this retardation due to lack of progress, as is commonly assumed? Or is the slow progress due entirely to lack of aptitude for school work? It was shown in the inquiry that more than one-third of the pupils in the schools were born outside of Philadelphia and largely in the Southern States, especially Virginia and Maryland. Those who thus enter begin late, first because they are accustomed to less schooling in their home communities, and secondly, because the change of residence causes uniform loss of attendance in every school. The retardation begun is accelerated in the adaptation to new conditions and the result is disastrous to progress and deportment. Again, the small number of Negro children in school at the ages of six and seven shows that the Negro pupils uniformly enter school later than white children. In addition to the causes already mentioned, there are various other influences, home conditions and shift- 
ing of population, which tend to contribute towards the result. Thus the element of population is large in the process of elimination. Again, the death rate for Negro children is higher than for white children, and consequently the elimination due to this is larger. While this would seem to be overbalanced by the influx of new children, it has been shown that these children only add to the amount of retardation which accelerates elimination.

It has been shown that the Negro children move from ward to ward and hence change schools more frequently than do white children. In the intervals time is lost and work is hindered. To poor attendance is ascribed a large part of the failure of Negro children. Poor attendance has a number of contributing causes. A review of the facts as reported by the trained nurses shows that the Negro children are often left to do as they wish. More than 60 per cent of the mothers work away from home. The children oversleep, or choose their own procedure. They are not infrequently required to run errands, and assist at home before going to school, or for parts of the day. They are hindered by neglect and carelessness, by interference, and by physical results of environment. The extent to which this is true has been pointed out. Poor attendance and a high percentage of lateness affect the quality of work seriously. But home conditions affect not only attendance and lateness but also the actual work in school. The quantity and quality of food and the manner of eating have been shown to be irregular and improper. The Negro children sleep irregularly and insufficiently. They use intoxicants to an unusual extent. They are affected to an unusually large extent with minor bodily afflictions, especially colds, head and throat troubles. Their conditions of bodily hygiene are bad. In some instances they are poorly clad. Thus the very physical basis of attention is undermined.

Again in school, partly as a result of the facts mentioned, partly because of innate traits, and partly because of home and race influences, the Negro children do not apply themselves to their work. Lack of study is often responsible for unsatisfactory work instead of inability to succeed in their studies. Especially is this true of their home study. There are few incentives to study at home, little favorable influence to promote it, and practically no facilities in the way of reading. Again Negro parents are unable to assist their children in most cases and are not always disposed to do so. The mothers and fathers working out, the promiscuous mingling and visiting, 
moral and other irregularities noted previously-all these contribute towards the difficulties in the way of Negro children.

In this way many other factors might be correlated with the poor resulting conditions of Negro children in the schools already enumerated. Under existing environment the retardation, attendance, promotions, quality of work and deportment are natural products. Inquiry was made into the home conditions of Negro pupils whose records were high. This inquiry reported only those pupils about whom there was no doubt in their classification. The results showed that the poorest homes furnished only a small per cent and that the best and average homes furnished about equal proportions. There was no verification of the assumption that all bright Negro children are mulattoes.

Some of the causes affecting the present status of Negro children in the schools have been suggested thus at length. Others may be studied from the context. So far as the results of this study up to this point are concerned, there is no evidence to show that Negro children differ from white children because of race. There is much evidence to show that they differ largely-whether because of environment or only in the midst of environment cannot be discussed here. It is absolutely necessary, therefore, to report an exhaustive and scientific study of more exact measurements before any conclusions can be reached in regard to race differences.

But for the present, neither the causes nor the processes serve to change the condition. Whatever they are it has been shown that Negro pupils constitute a separate problem of education in the scbools and it is necessary to interpret the meaning of facts, regardless of their causes. Then when the more exact causes have been determined it will be possible to know the more exact significance of the facts reported.

It will be seen that the problem of the Negro child has two distinct larger meanings. The first is the effect of the present conditions upon the successful application of the present school system to Negro children. Rated according to the usual standards, it has been shown that the schools are not successful in teaching Negro children. These children are not receiving education approximating their needs either for liberal training or industrial work. It is scarcely possible to place the blame entirely upon the Negro children. The second meaning of the facts has to do with the effect which this slow rate of progress 
and over-age has upon the white children, involving the working efficiency of the whole school system. If the eight thousand Negro pupils in the schools, of whom more than 5,500 are retarded, were all grouped together, the problem would involve only about that number of retarded pupils. But these Negro children are enrolled in many schools involving primarily more than 60,000 children. Because of the dull Negro pupils in each class, the teachers claim that the entire class must lose much time and thus the rate of progress and the degree of efficiency are lowered. This repetition of time on the part of the teachers varies from almost 40 per cent in the more difficult subjects to a much smaller amount in easier studies. If this repeated teaching is not given, the Negro pupils suffer and thus add to the already high percentage of retardation. Unfortunately, there is no way of measuring this loss and subtracting the degree of similar losses in the same classes because of dull white pupils, in order to ascertain the median generic loss caused by the retarded Negro pupils in each subject and grade.

It is possible, however, to estimate the number of years lost by Negro pupils in the aggregate. That is, the number of years represented in the total over-age pupils is a measure of ultimate loss which the Negro pupils sustain through elimination and retardation. This loss is not always a loss in expense to the city by any means, for, as has been shown, late entrance accounts for much of the Negro pupils' retardation. It does in every case, however, show the relation between the over-age pupil and the normal pupil, and some inference may be drawn as to the extent to which normal pupils are hindered and loss of time incurred.

If the aggregate years of pupils over-age be calculated for the white children, there would be 87,242 such years or approximately six months for each child reported. If the same aggregate for Negro children be calculated there would be 13,842 such years or approximately twenty-one months for each Negro enrolled. That is, of the total years above normal age for all children, 101,084, Negro children have more than 12 per cent. These years of retardation may not cost a large amount of money, but tax the efficiency of the schools. This cost to efficiency, caused by the retarded pupils, is further intensified by the prejudice existing in the minds of white pupils and teachers. This difficulty may be understood when it is remembered that the white teachers are teaching day after day a group of children in 
whom the majority can see few strong points. The full meaning of the present situation cannot be discussed adequately until the studies of exact measurements, comparisons of Negro children in mixed and separate schools according to uniform school tests, and comparison of teaching efficiency in the white and Negro schools have been reported. Meantime it is well to proceed with the second division of this inquiry.

\section{Tests of General Intelligence and Mental Processes}

It is perhaps an accepted theory that the influence of environment is much more powerful in the displacement of an individual or group downward than upward. That is, unfavorable environment may easily retard or warp growth, and take away from their highest possibilities the energies that make a high mental or physical development possible. While favorable environment, likewise, has its strong influence in developing mental and physical energies to their natural consummation, it can rarely raise them beyond their natural abilities. Suppose a group of individuals of median abilities be divided into two parts, the one placed under favorable environment, the other under unfavorable environment. The part living under unfavorable environment will furnish a larger proportion of the exceptionally inferior, than will the other group of exceptionally superior; or to consider the individual, a person of only the median ability cannot be raised to the rank of the most exceptional superiority by any environment, whereas, the individual of median ability may often be reduced by environment to the most exceptionally inferior. ${ }^{2}$ Now this fact is of special significance in the study of Negro children. On the one hand it lends support to the conclusion that the failure and defects of Negro children may be due only to environment which is unfavorable to their highest development. There is, thus far, no evidence to contradict such a conclusion, while there is much evidence to show that the environment under which Negro children have grown is unfavorable to the development of the mental abilities commonly accepted as superior. But on the other hand, it may lend evidence to the conclusion that no environment, however good and however much of favorable training and positive impetus it might offer, can raise individuals of only moderate efficiency and intelligence to a station of superiority.

${ }^{2}$ See Thorndike's Educational Psychology, p. 210. 
Now it has been shown that Negro children show a large proportion of inferior inefficiency in certain accepted fields according to certain accepted methods of rating. They also show a certain proportion of apparently exceptional superiority in certain processes and activities. Here again the results indicate, on the one hand, that Negro children conform to the conditions in which environment is the chief factor in determining the results; and likewise, owing to admixture of white blood, and owing to the inaccuracy of measurements, there is no evidence to show that they do not appear to furnish only mediocre native abilities at the best. With only this knowledge at hand, it is absolutely impossible to say bow much and of what sort are the innate differences between white and Negro children. So far the inferiority of Negro children in school efficiency has been reported only in terms of very general estimates and the study and correlation of even immediate environment showed sufficient influence to bring about present conditions. But no tests of efficiency in specific processes have been made and no relative standard of intelligence established. It is necessary, therefore, to measure with methods of scientific precision the mental and physical traits of the median group of Negro children and to report the results in terms of objective units. These must then be compared with similar exact measurements of the median white children. Next the exceptionally inferior and the exceptionally superior children must be studied and the nature of the basis of their inferior and superior qualities be ascertained so far as is possible. These measurements must include both mental and physical processes and their combinations and so far as possible the total intelligence of the children. When this has been done it will be possible to rate any differences that may be of long standing, inherent, if not inherited, and upon this base a knowledge of the fundamental needs and perhaps possiblities of the children may be built. Upon this basis, too, may be begun studies of actual racial psychology and important aspects of American education.

First, it is necessary to study mental processes. The list of important aspects of total mentality which might be tested, is almost unlimited. However, certain generally accepted fundamental processes may be tested and their quickness, breadth, intensity and strength ascertained. The physical basis and motor processes may then be studied and correlated. But as a preparation for such inquiry let the total intelligence of the children be measured according to 
some accepted and approximately accurate standard. Such a standard should be apart from knowledge gained primarily in the school room, and should test only general intelligence. Such a test is found in the Binet measuring scale of intelligence which furnishes a simple but accurate test for each year up to fourteen years of age. The test for the fourteenth year was entirely impractical but the other tests were used with every precaution for accuracy. The method was the same as that used by Goddard and the tests for Negro children accordingly compared with those made upon whites by Dr. Goddard. ${ }^{3}$ The number of white children tested by Dr. Goddard was 1,547 and the number of Negro children tested in this study was 300 , the number being unavoidably limited, but the selection a fair chance selection.

Of these numbers the white children showed 21 per cent testing one year above age and 20 per cent testing one year below age, while the Negro children show only 5 per cent one year above age and 26 per cent one year below age. Negro children show 6.3 per cent feebleminded as compared with 3.9 per cent white children. The figures for the white children conform closely to a normal curve while the upper half of the curve for Negro children is almost entirely wanting. The median for the white children falls within the "at age" period while with Negro children it falls decidedly at "one year below age." Taking three years, one above age, at age, and one below age, as "normal" and plotting the curves the result is almost identical to the similar curve plotted for normal, below and above normal age as indicated in the grade distribution already described, indicating that the school grading and the Binet tests coincide so far as the classification of Negro children is concerned.

The total averages, however, do not represent the tests accurately in the case of Negro children. The Negro children at five, six and seven years test about normal, while the older children test far below normal. Those at five years test 5.1 years, while the fifteen year old children tested only 11.3 years. The average thus goes from 0.1 year above to 3.7 years below age.

The following table gives the average intelligence for each year and the number tested.

Here again it will be necessary to have a larger number of tests, and also to make other tests in order to ascertain the accuracy of the tests for the older children.

${ }^{3}$ See The Training School, January, 1910, and 1911. 
Further detailed study of the tests for each year reveals other important considerations. The tests for the sixth year were answered by a larger per cent of Negro children of that age than of white children. In the seventh year Negro children were approximately as good as the white, and thence they decrease to the thirteenth year regularly until at that age no Negro children thirteen years of age passed the test. In only the sixth and seventh years could more than 50 per cent of the Negro children pass the test for their ages so that the question is raised as to whether the tests are not misplaced in this instance and whether it is quite fair to use the same standards with Negro children as with white children.

A second general test was given to supplement the Binet tests with better results. The completion method of Ebbinghaus was used

Average Intelligence of Negro Children

\begin{tabular}{c|c|c|c}
\hline Age & Number of pupils & $\begin{array}{c}\text { Average age by Binet } \\
\text { tests }\end{array}$ & $\begin{array}{c}\text { Average amount } \\
\text { backward (years) }\end{array}$ \\
\hline 5 & 10 & 5.1 & 0.1 (above) \\
6 & 33 & 5.6 & 0.4 \\
7 & 42 & 6.7 & 0.3 \\
8 & 45 & 7.3 & 0.7 \\
9 & 36 & 7.2 & 1.8 \\
10 & 37 & 8.6 & 1.4 \\
11 & 33 & 9.5 & 1.5 \\
12 & 20 & 10.5 & 1.5 \\
13 & 23 & 10.4 & 2.6 \\
14 & 13 & 10.7 & 3.3 \\
15 & 8 & 11.3 & 3.7 \\
\hline
\end{tabular}

with a view to testing children on their ability "to combine fragments or isolated sections into a meaningful whole." ${ }_{4}$ The test was given to white and Negro children from eleven to fourteen years of age. The text contained 93 elisions. The average number correct for the white children was 56.4 and for the Negro children 47.5. Ten per cent of the white children returned incoherent completions and 35 per cent of the Negro children. Thirty-five per cent of Negro children made completion by phrase only as opposed to 10.8 per cent of white children. The mode for white children ranged from fifty to seventy and for Negro children from forty to fifty.

- The test is given in Whipple's Manual of Mental and Physical Tests. 
Next came the tests for "single traits," the first of which was Thorndike's "A" test for simple perception, the results being graded according to the number of "A's" marked regardless of the number omitted. Three hundred and ten white children and 275 Negro children were tested with the result that Negro children showed a higher average of performance and a wider range of variability, the Negro ehildren marking an average of 21.9 and the white children 19.3 while the average deviation for the Negroes was 6.9 and for the whites 4.2. The curve for the white children tends to conform to a normal curve of distribution while that for the Negro children is flat and irregular.

The next test given was Thorndike's " $\mathrm{A}-\mathrm{t}$ " test for association of ideas, thus taking one step more. The same number of children were tested with the result that white and Negro children are approximately equal in average performance but Negro children again show larger deviations. The average performance of white children was 16.9 and for Negro children 16.6 and the deviations being 3.7 and 4.2 respectively. Here again the curve for white children conforms more closely to the normal distribution, the whites excelling in the mode and average and the Negroes in variability and range.

The next test added to association of ideas and perception, controlled association as suggested in Thorndike's "opposites" test. Here the difference between the two groups was much larger, the average for the whites being 13.2 and for the Negroes 10.5, and still the deviation for the Negroes was 4.4 as opposed to 3.6 for the whites. The curve for white children tends again to normal while that for Negro children is multimodal and very irregular, being exactly the opposite of the whites for whom the test was a little too easy, it being a little too difficult for completion by the Negro children.

The next test combines association of ideas and controlled association with some knowledge and facility in spelling as outlined by Thorndike's misspelled word test. In grading according to efficiency in marking misspelled words the difference was found to be greater than in other tests. The white children have 10.6 per cent who mark from 90 to 100 while the Negro children have only 1.5 per cent. The white children showed only 1.3 per cent who marked under 20 while the Negro children showed 10.8 per cent. The mode for the white children was at 80 and for the Negro children at 30 . The average for 
white children was 69.6 and for Negro children 50.6 while the deviation for Negro children was again larger than for white children, and the curves are similar to those of other tests. In grading the same test according to the number omitted the same results were noted, a lower efficiency and larger deviation.

Thus in these tests ranging from the simplest to more complex the Negro children tend to decrease in efficiency as the complexity of the process increases, as compared with white children. In the first they excel slightly; in the second they almost equal the performance of the whites; in the third they fall eonsiderably below and in the fourth very much below. In all cases the deviation is considerably larger for the Negro children, thus raising very important considerations.

\section{Conclusion}

Further tests and measurements of white and Negro children might have been carried to an almost indefinite extent with profit. But the limit of this study, bounded by the facilities at hand, had been reached, and sufficient data obtained to permit brief summaries, conclusions and discussions of the relative differences between white and Negro children in their school environment.

In considering the data given it must be remembered that they apply to Negro children as they are found today, the product of inheritance and environment, and that the question of inherent race traits, in the strictly anthropological meaning, is entirely apart from the present discussion. It is hoped that researches into race differences will be aided by the facts reported in this study, but that is not the main object of this inquiry. If the cumulative influence of immediate and remote ancestry on the one hand, and immediate and remote environment on the other, has been such as to bring about present conditions, it is essential to analyze these conditions and undertake to determine what further influences will bring the best results from continuing inheritance and environment. There can be no doubt as to the problem from the practical viewpoint of efficiency in education or from the viewpoint of accepted principles of education, psychology, and anthropology.

It may be repeated that in a problem of such long-developed standing and complexity, both in itself and in its relation to environment, final conclusions cannot be reached at once. Dogmatic assertions and hasty recommendations should be avoided and the full force 
of study and recommendation be directed toward further research and the application of knowledge and means now available.

With these qualifications in mind, conclusions may be reached which will be of value in attempting to solve the pedagogical and administrative problems involved and in placing the entire question on a scientific basis. The study has shown conclusively that there are distinct differences between white and Negro children in all three of the aspects studied, namely, environment, school conditions and progress, and in mental and physical manifestations. The study of home environment shows that Negro children are at a disadvantage, in social and moral influences and in actual physical conditions, comprising food, drink, sleeping accommodations, and general hygienic conditions. In addition to the general social influences of crowded conditions and lower standards, the children are handicapped by poor air, water, food and irregular exercise and rest. Finally they receive little intelligent supervision and coöperation at home in maintaining a continuous connection with school and mental effort, and when leaving school face restricted opportunities for obtaining a livelihood.

The differences in school attendance and progress are equally large. Negro children show much greater retardation measured by both age and progress; a much lower percentage of attendance and higher percentage of irregularity; a lower percentage of promotion and a lower average of class standing. Great as these differences are, the influence of environment alone seems to be sufficient to account for the majority of the results. It appears, therefore, that injustice would be done to Negro children if harsh judgment be passed upon them because they do not maintain the standard of the white children. The fact that the records of a limited number of Negro children equal the records of the best white children gives indication of larger possibilities.

But the differences between the two groups do not end with environment and school progress. The exhaustive study of conditions of school progress indicated that there were differences in kind as well as in amount. The results of the tests, applied uniformly to white and Negro children, show that in their manifestation of general intelligence, Negro children, after the age of eight years, are behind the white children; that in single traits and processes these older children differ from the white children materially; that in comparison with white children the efficiency of Negro children varies inversely 
as the complexity of the process; but that in practically all instances the deviations for Negro children are larger than for the white children; and in many cases the individuals among the Negro children range as high as those among the white children. The white children tend always to conform to a normal curve of distribution, and the Negro children tend toward a flat, irregular, and not infrequently, multimodal curve. These facts apply to both normal and backward children.

As far as the data presented show, the differences in physical measurement of height, weight, neck and chest measurements, and temperature, respiration, and pulse, are much less and show less consistency in variation, and appear more traceable to the influence of immediate environment than do other differences.

That these facts are significant there can be little doubt. That they present certain complex problems is entirely consistent with the inevitable results of a long and varied race inheritance combined with an equally varying environment. If, as Professor Boas concludes, "Even granting the greatest possible amount of influence to environment, it is readily seen that all the essential traits of men are due primarily to heredity" and if further "we must conclude that the fundamental traits of the mind . . . . are the more subject [than physical traits] to far-reaching changes"6 and "we are necessarily led to grant also a great plasticity of the mental make-up of human types," it would clearly be impossible for the Negro children to show the same manifestations of mental traits as white children, after having been under the influence of entirely different environments for many generations.

This conclusion also brings with it a great responsibility. The fact that such important differences exist between the white and Negro children and that they have arisen naturally through long periods of growth in different environment, brings with it an obligation to determine the exact nature of the differences, their specific causes, and the means by which a new environment and method may overcome such weaknesses as are found. The fact that the Negro children show great variablility in all activities combined with the accepted theory of the plasticity of human types, gives indications of great possibilities in

- The Mind of Primitive Man, p. 76.

- Changes in Bodily Form of Descendants of Immigrants.

${ }^{7}$ Ibid. 
the development of the Negro. But it also characterizes all efforts to deny the existence of fundamental differences between the white and Negro children as inconsistent and harmful to the development of the Negro race, on the one hand, and to the permanent adjustment of conditions on the other.

The importance of these considerations may be emphasized further by referring to certain specific results of the study. For instance, the results of the Binet tests indicated that after the eighth year the median Negro child was unable to perform the intellectual processes commonly ascribed to a normal white child of that age. Apparently the Negro children found it very difficult to go beyond their inheritance of simple mental processes and physical growth. But they exercise to a high degree of efficiency the simple processes which, if coördinated, would lead to a higher degree of general intellectuality. Favorable environment can add nothing; it can only develop the qualities already possessed. If, then, it is possible to know the exact defects in development, and the nature of the traits possessed, it will be possible to develop the inherent energies and qualities in the right channels provided the method of training shall involve sufficient detail and extend over sufficient time. Herein lies the great value of defining the exact differences between the several groups of children involved; for in this way only can efficient training for the development of native energies be provided. This is the basis of the great advance in modern intellectual methods and is entirely in accord with accepted anthropological knowledge.

Responsibility does not end, however, with the effort to provide education which will ultimately develop the children into their highest capabilities. The present and immediate future must be provided for. The great majority of Negro children not only do not enter the bigh school but also fail to complete the elementary grades. Less than 2 per cent of the Negro children of school age reach the eighth grade. Furthermore, their training to the period of dropping out of school fits them neither for any special work in life nor for competing with the more fortunate and better fitted in society at large. The opportunities for employment of Negro children thus equipped are limited, and they are forced to continue the struggle under even more unfavorable conditions. Add to all the inequalities already mentioned the fact that the standard of excellence, toward which white and Negro children unconsciously strive, is often entirely different. An indi- 
vidual among the whites and an individual among the Negroes may each measure up to the maximum ideal of his habitual social and mental horizon and each deserve 100 per cent credit, and yet the objective measure of final achievement may be larger in the one case than in the other. What then, can the school and society expect of children to whom they give neither-special training for life nor equal opportunity in the struggle? Here again the basis of improvement is found in the exact definition of conditions as they are and a recognition of their significance.

It follows that from the community standpoint an effort should be made not only to provide proper education and vocational training and guidance, but the present unfavorable conditions should be so remedied as to influence the smallest possible number of children and schools. If the lack of adaptation of children to the curricula is costing the community thousands of dollars annually and is at the same time a hindrance to school efficiency and progress, and if even at this great cost the desired objects are not obtained, can there be doubt concerning the need for a more definite program? 